Military Technical College Kobry El-Kobbah, Cairo, Egypt

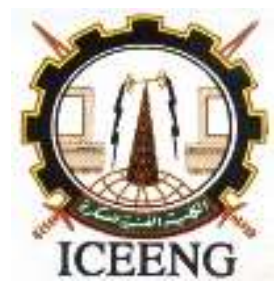

\author{
$11^{\text {th }}$ International Conference \\ on Electrical Engineering \\ ICEENG 2018
}

\title{
Wake Effect on the Construction and Cost of Variable Speed Wind Farm
}

\author{
Hassan H. El-Tamaly* and Ayman Yousef Nassef**
}

\begin{abstract}
This paper focuses on construction of wind farm, variable speed wind farm operation and weak effects on the power production from wind farm by using Jensen's weak model. This methodology can be done by using Matlab program.

The objective of every wind farm designer is producing as maximum, as possible of energy, with minimal cost of installation. The optimization is done by the minimum cost per unit of energy produced. In this study an algorithm has been developed to solve the rule of thumb a wind farm layout based on the wake model of Jensen. It has the capacity to estimate the optimal number of total power produced in wind farm, in comparison with predominant wind farm. Five different wind turbines types have been used.
\end{abstract}

\section{KEY WORDS}

Wind Turbine Module, Wind speed, Wake effect, Matlab program.

\section{Introduction}

If a wind turbine is working within the region of the wake of another turbine, or at a point within the wind farm which is affected by several of these wakes, then the turbine will produce less energy than those turbines that interact directly with the natural wind flow. Therefore the layout of wind farms is very important, since it has impact in the economic, safety and reliability evaluations of the system.

*Professor of Electrical Power Engineering,Faculty of engineering, Minia University, Elminia, Egypt Member of Steering Committee of International MiddleEast Power Systems Conference, Mepcon.Member of Electricity \& Energy Researches Council, Academy of Scientific Research \& Technology.

${ }^{* *}$ Engineer in Middle Egypt Company for Electricity Distribution, Elminia, Egypt. 


\section{Modification of Average Wind Speed to Hub Height}

Usually weather stations measure wind speed at $10-\mathrm{m}$ or $24.5-\mathrm{m}$ above the ground. If these heights do not match the hub height of a wind turbine it is necessary to extrapolate the wind speeds to hub height of the turbine [1,5]. This process can be done by the following equation:

$$
u_{h}=u_{h o} *\left[\frac{h}{h_{o}}\right]^{\alpha}
$$

Where: $u_{h}$ is the wind speed at height of $h-m$ above the ground, $\mathrm{m} / \mathrm{s}$, uno is the wind speed at height $h_{o}-m, m / s,\left(h_{0}\right.$ is used $24.5 m$ ), $h$ is the height of turbine from ground, $\mathrm{m}$ and $\alpha$ is wind shear power law exponent. The wind shear power law exponent depends on the specific site. It is often equal to or near the value 1/7.

\section{Wind turbine model}

The power $\mathrm{P}_{\mathrm{wt}}$ produced by the WT within the rotational speed interval [ $\mathrm{n}_{\min } ; \mathrm{n}_{\max }$ are proportional to the WTs blade radius $R$, air density $\rho$, wind speed $u$ and a coefficient $C_{P} \cdot[1,3,10]$

$$
P_{w t}=C_{p}\left(\frac{1}{2} \rho A_{w} u^{3}\right)=\frac{1}{2} \rho A_{w} u^{3} C_{p}(\lambda, \beta)
$$

Where; $C_{p}$ is the coefficient of performance, $P$ is the air density, is equal 1.225 $\mathrm{kg} / \mathrm{m}^{3}$ at sea level at temperature $T=298 \mathrm{~K}, A_{w}$ is the swept area of the turbine, $\mathrm{m}^{2}$ and $u$ is the wind speed, $\mathrm{m} / \mathrm{s}$.

Maximum value of $C_{p}$ is defined by the Betz limit, which states that a turbine can never extract more than $59.3 \%$ of the power from an air stream. In reality, wind turbine rotors have maximum $\mathrm{C}_{p}$ values in the range of $25-45 \%$.[1]

The coefficient of performance is not constant, but varies with the wind speed, the rotational speed of the turbine, and turbine blade parameters such as angle of attack and pitch angle. Generally, it is said that power coefficient, $C_{p}$, is a function of tip speed ratio, $\lambda$, and blade pitch angle, $\beta$ (deg). The tip speed ratio is defined as:[ 3,10$]$

$$
\lambda=\frac{w_{R} r_{m}}{u}
$$

Where: $r_{m}$ is The maximum radius of the rotating turbine, $m, w_{R}$ is The mechanical angular velocity of the turbine, $\mathrm{rad} / \mathrm{s}$.

The angular velocity $W_{R}$ is determined from the rotational speed $n(r / m i n)$ by the equation.

$$
w_{R}=\frac{2 \pi n}{60}
$$

Where; $\mathrm{n}$ is the rotational speed, revolution per minute

Numerical approximations have been developed to calculate $C_{p}$ for given values of $\beta$ and $\lambda$. Here, the following approximation is used $[2,6,10]$ 


$$
C_{p}(\lambda, \beta)=0.73\left(\frac{151}{\lambda_{i}}-0.58 * \beta-0.002 * \beta^{2.14}-13.2\right) e^{\frac{-18.4}{\lambda_{i}}}
$$

Where $\lambda_{\mathrm{i}}$ is described by the equation:

$$
\lambda_{i}=\frac{1}{\frac{1}{\lambda+0.02 * \beta}-\frac{0.03}{\beta^{3}+1}}
$$

At rated wind speed, the rated electrical power output can be expressed as:

$$
P_{e R}=C_{P R} \eta_{m R} \eta_{g R} \frac{\rho}{2} A_{w} u_{R}^{3}
$$

Where: $C_{P R}$ is the coefficient of performance at the rated wind speed $u_{R}, \eta_{m R}$ is the transmission efficiency at rated power, $\eta_{\mathrm{gR}}$ is the generator efficiency at rated power, $\rho$ is the air density, and $A_{w}$ is the turbine area. The efficiency for a gearbox or transmission efficiency is typically $90-95$ percent and the efficiency for a generator is from around 90 percent to almost 100 percent $[11,10]$.

The quantity CPR $\eta_{\mathrm{mR}} \eta_{\mathrm{gR}}$ is the rated overall efficiency of the turbine. This quantity can be represented by a symbol of $\eta_{0}$ :

$$
\eta_{o}=C_{P R} \eta_{m R} \eta_{g R}
$$

The electrical power output of a wind turbine is a function of the wind speed, the turbine angular velocity, and the efficiencies of each component in the drive train.

It is also a function of the type of turbine, the inertia of the system, and the gustiness of the wind. The average power $\mathrm{P}_{\mathrm{e}, \text { ave }}$ that would be expected from a given turbine at variation in wind speed.[10]

$$
P_{e, a v e}(t)=\left\{\begin{array}{ll}
\mathrm{O}, & u<u_{c} \\
C_{P R} \eta_{m R} \eta_{g R} \frac{\rho}{2} A_{w} u_{R}^{3} & u_{c} \leq u<u_{R} \\
P_{e R}, & u_{R} \leq u<u_{F} \\
0, & u \geq u_{F}
\end{array}\right\}
$$

Where; $P_{e R}$ is rated Power of WTG, W, $u_{c}$ is cut-in wind speed, m/s, $u_{R}$ is rated wind speed, $\mathrm{m} / \mathrm{s}$ and $\mathrm{uF}_{\mathrm{F}}$ is furling wind speed, $\mathrm{m} / \mathrm{s}$.

\section{Turbine Placement}

Turbines will typically be placed in rows perpendicular to the prevailing wind direction. We will define two turbine spacing, $D_{\mathrm{cw}}$ as the cross wind spacing within a row of turbines as from two to four rotor diameters, and $D_{d w}$ as the downwind spacing between rows of turbines the range of from five to ten. These are calculated as constant times the number of rotor diameters D. Spacing the turbines further apart will produce more power, but at the expense of more land, more roads, and more electrical cables. [1]

\subsection{Wind turbines type, number and placement modeling considerations}

The main goal is to determine the optimal wind turbines type, number and placement to get maximal power output while minimizing the investment costs and considering different practical requirements and restrictions. 
In this paper the comparative study will be done between two cases, the first case is predominant wind farm module and the second case is the thumb wind farm module as shown in Fig. 1 [3]. The downwind spacing $D_{d w}$ is varying from 5 rotor diameters to 10.5 rotor diameters in rows and the cross wind $D_{c w}$ is 3 rotor diameters Coolum apart for two cases.

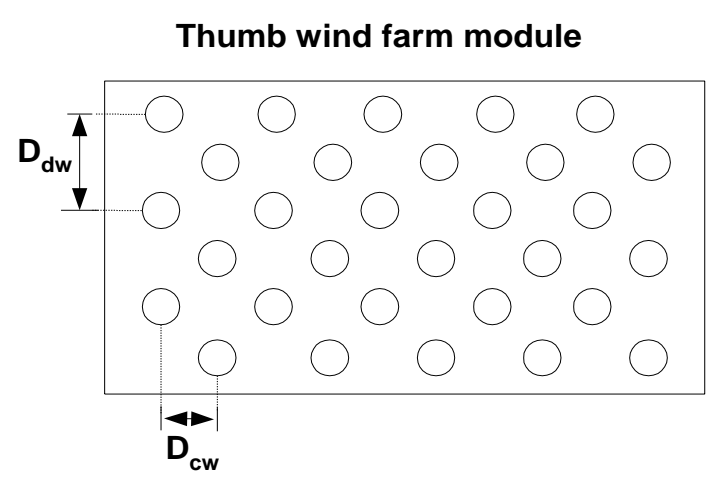

(a)

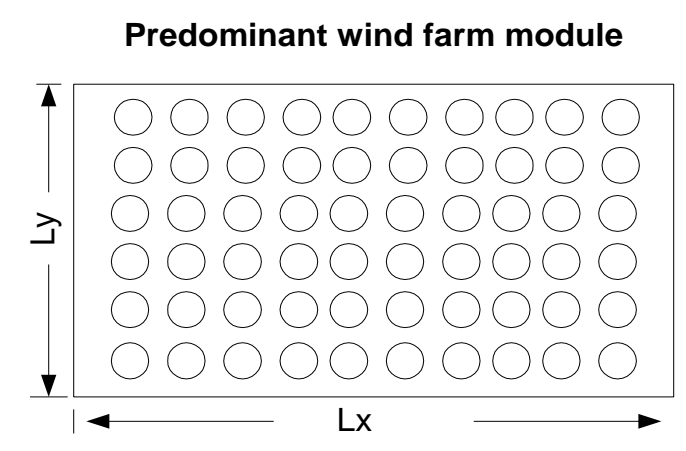

(b)

Fig. 1 Wind turbines sample placement for: (a) thumb wind farm module (b) for predominant wind farm module.

The number of wind turbines in a row $\mathrm{N}_{\text {row }}$, and number of wind turbines in a column $N_{c o l}$ can be determined for given area with length $D_{\text {row }}$ and $D_{c o l}$ taking into consideration the separation distances between turbines $D_{d w}$ and $D_{c w}$ as in ref. [1]:

$$
N_{\text {row }}=D_{\text {row }} / D_{d w}+1
$$

Analogically, the number of wind turbines in a column $\mathrm{N}_{\text {col }}$ can be determined as:

$$
N_{c o l}=D_{c o l} / D_{c w}+1
$$

The total number of turbines $\mathrm{N}$, can be defined as multiplication of rows and columns turbines numbers $\mathrm{N}_{\text {row }}$ and $\mathrm{N}_{\text {co I }}$.

$$
N=N_{\text {row }} N_{c o l}
$$

\subsection{Wake Effects and the Cost Model}

To estimate the power produced from a wind turbine operating in the wake of one or more wind turbines, an analytical wake model developed by Jensen [3, 4,7 and 9] is chosen. It is based on global momentum conservation in the wake downstream of the wind turbine as shown in Fig. 2. The wake effect can be determined as Equation (13) $[4,7$ and 8$]$

$$
u_{j}=u_{o}\left(1-u_{\text {def }}(j)\right)
$$

Where; $U_{j}$ is the wind set of turbines affecting position $j$ with a wake and $u_{d e f}(j)$ is the wind affecting position $\mathrm{j}$ with a wake. 
Fig. 2 Wake from a single wind turbine

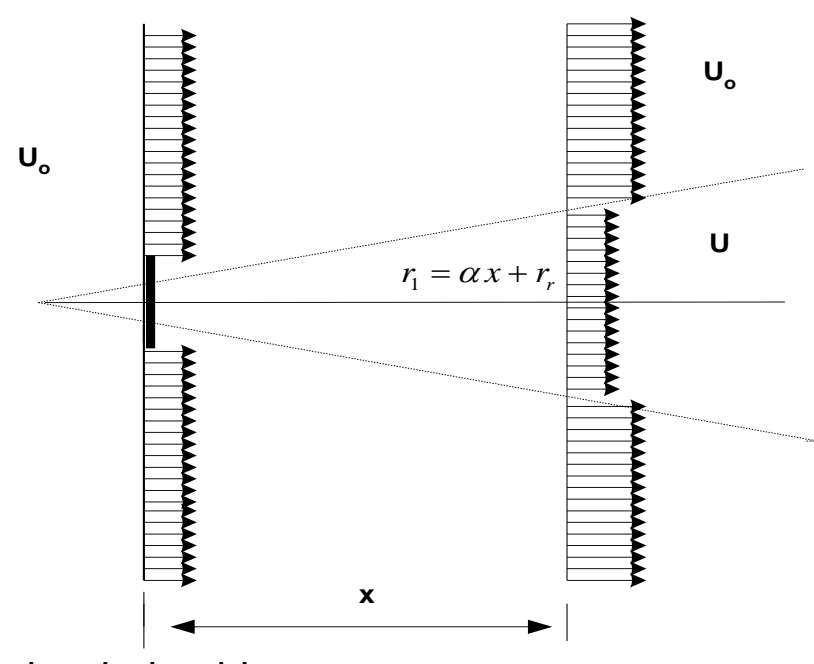

To determine the cost of the wind farm, a cost model is selected. The model chosen was also used in previous studies [8]. The total cost per year for the entire wind farm can be expressed as: [6]

$$
\text { Cost }=N\left[\frac{2}{3}+\frac{1}{3} e^{-0.00179^{k} N^{2}}\right]
$$

The objective function that will lead to optimization (minimum cost per unit of energy produced) is expressed as:

$$
\text { Objective function }=\frac{\text { Cost }}{P_{e, \text { ave }}}
$$

\section{Results}

In this study, the use of five types of wind turbines and the hourly wind speed for the selected site is the first data required for design of wind farm. The data has been obtained from the Egyptian Metrological Authority for Gable Elzait site at Gulf of Suez, Egypt [8]. Figure 3 shows the hourly wind speed over the year.

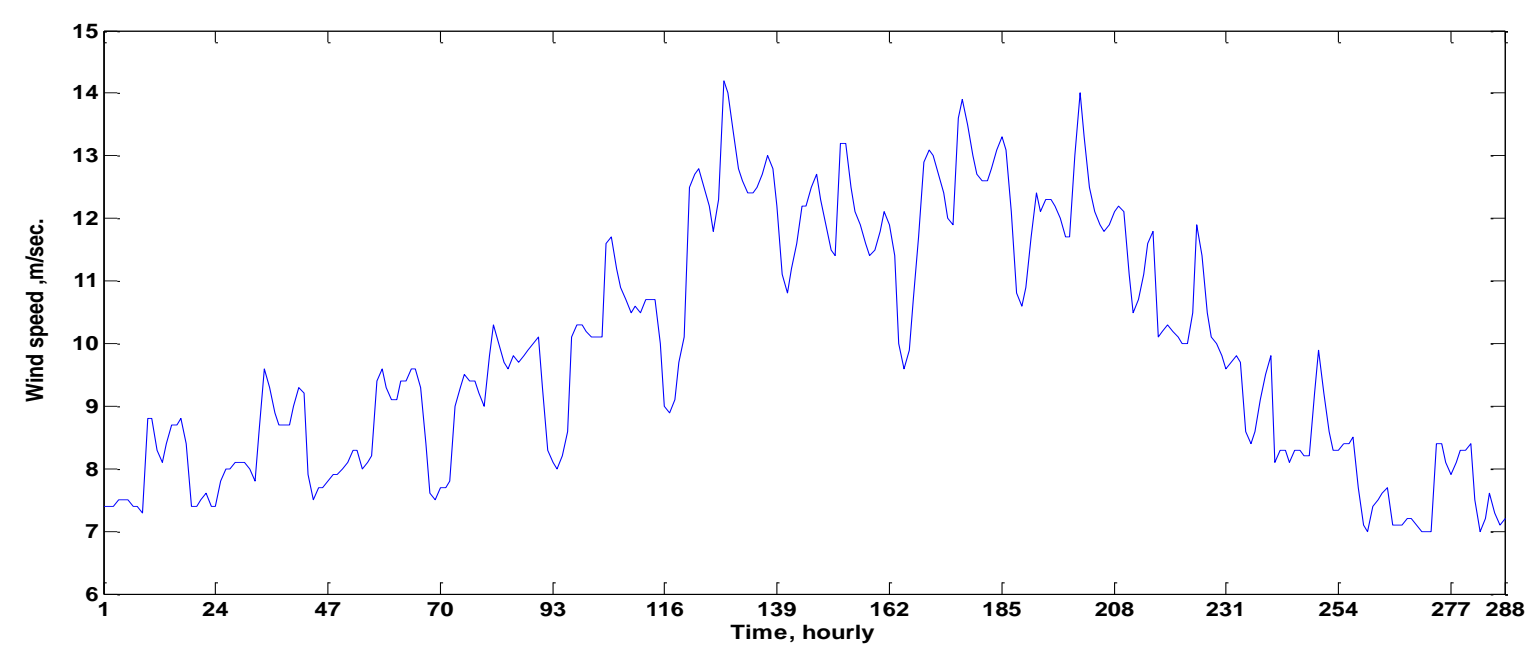

Fig. 3 : The hourly wind speed over the year.

MATLAB software has been used to design the program to find the most suitable setting for the turbines to the maximum power. To determine a situation of turbines 
ratios and optimum number of wind turbines the distance between each column has been taken to be $3 \mathrm{D}$ and the distance between the rows has been changed from $5 \mathrm{D}$ to $10.5 \mathrm{D}$. Table (1) shows the wind turbine characteristics.

TABLE-1: Characteristics of the selected WTG's

\begin{tabular}{|r|c|c|c|c|c|c|c|c|}
\hline $\begin{array}{c}\text { Charact. } \\
\text { Type }\end{array}$ & $\begin{array}{c}\mathrm{P}_{\mathrm{R}} \\
\mathrm{MW}\end{array}$ & $\begin{array}{c}\mathrm{U}_{\mathrm{c}} \\
\mathrm{m} / \mathrm{s}\end{array}$ & $\begin{array}{c}\mathrm{U}_{\mathrm{R}} \\
\mathrm{m} / \mathrm{s}\end{array}$ & $\begin{array}{c}\mathrm{U}_{\mathrm{F}} \\
\mathrm{m} / \mathrm{s}\end{array}$ & $\begin{array}{c}\mathrm{H} \\
\mathrm{m}\end{array}$ & $\begin{array}{c}\mathrm{D} \\
\mathrm{m}\end{array}$ & $\begin{array}{c}\mathrm{Aw}, \\
\mathrm{m}^{2} \\
{ }^{*} 10^{3}\end{array}$ & $\begin{array}{c}\text { Operation } \\
\text { interval rpm }\end{array}$ \\
\hline GE 1.6 & 1.6 & 3.5 & 11 & 25 & 96 & 100 & 7.854 & $9.75-16.2$ \\
\hline SWT 4 & 4 & 5 & 11 & 25 & 89.5 & 130 & 13.3 & $5-13$ \\
\hline FD77 & 1.5 & 3 & 11.5 & 21 & 74 & 77 & 4.657 & $11.1-18.1$ \\
\hline Repower & 6.15 & 3.5 & 14 & 30 & 95 & 126 & 12.469 & $7.7-12.1$ \\
\hline CT3000 & 3 & 3.5 & 11.7 & 25 & 90 & 103.94 & 8.48 & $8.34-15.73$ \\
\hline
\end{tabular}

The distributions of wind turbines in wind farm design have strong impact on the wind speed and also the power generated from wind farm. Effect of distance between turbine on yearly energy production for predominant wind farm and thump wind farm is shown in Fig.4. Figure 5 shows wind speed with wake effect on wind farm: (a) wind speed at row1 (b) wind speed at row2 (c) wind speed at row3: (d) wind speed at row4.

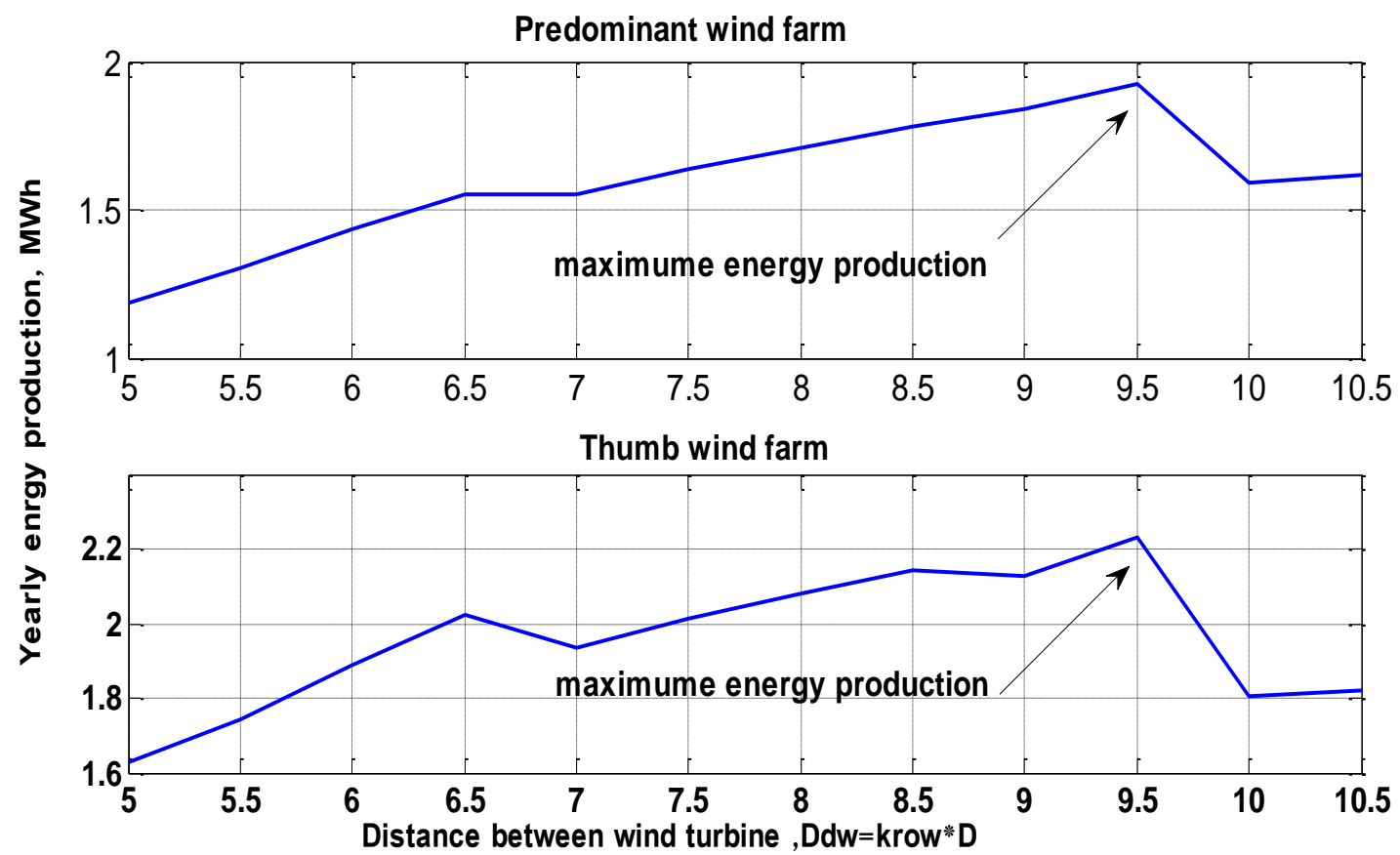

Fig. 4: Effect distance between turbines on yearly energy production for predominant wind farm and thump wind farm 
(a)

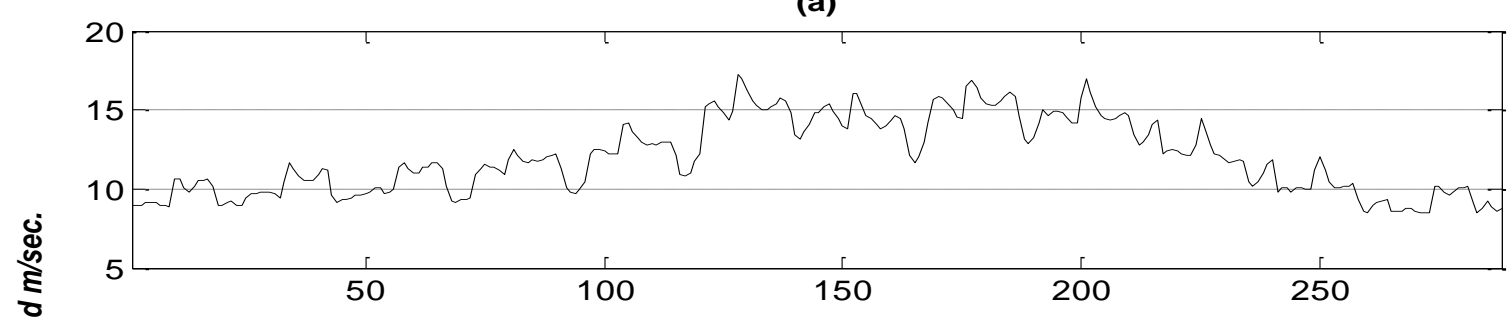

(b)

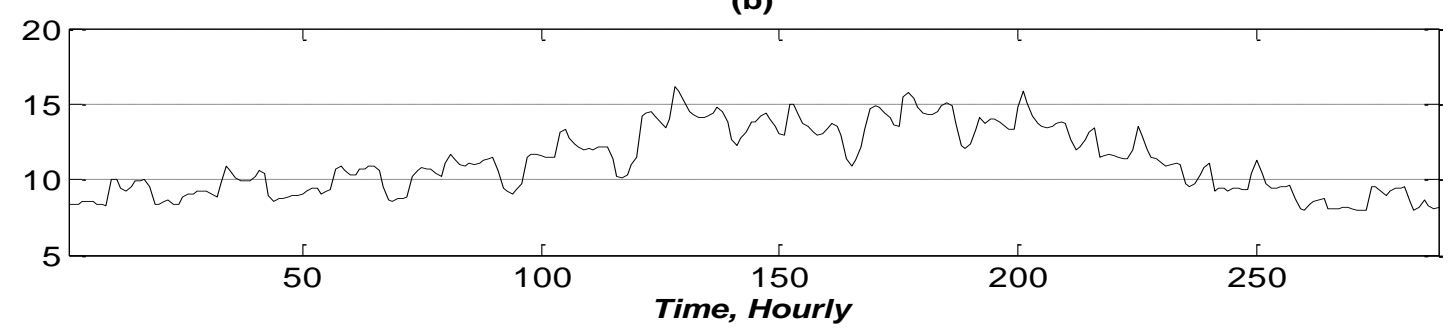

(c)

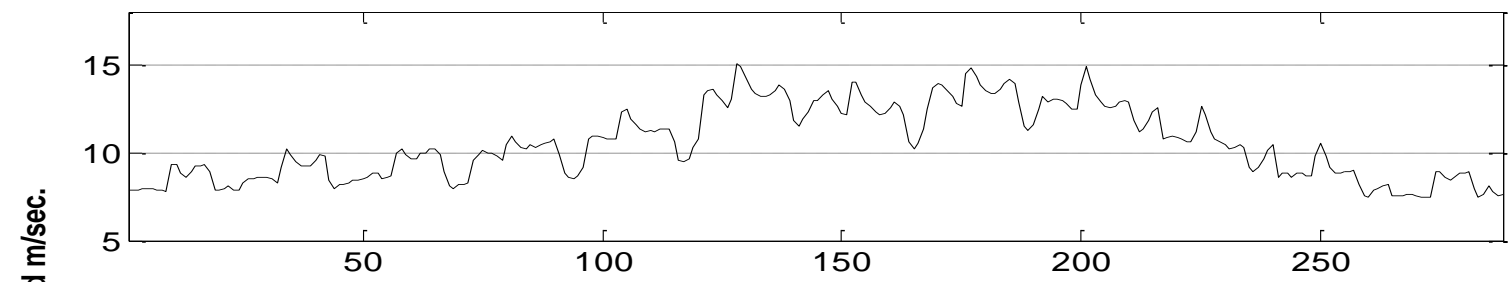

(d)

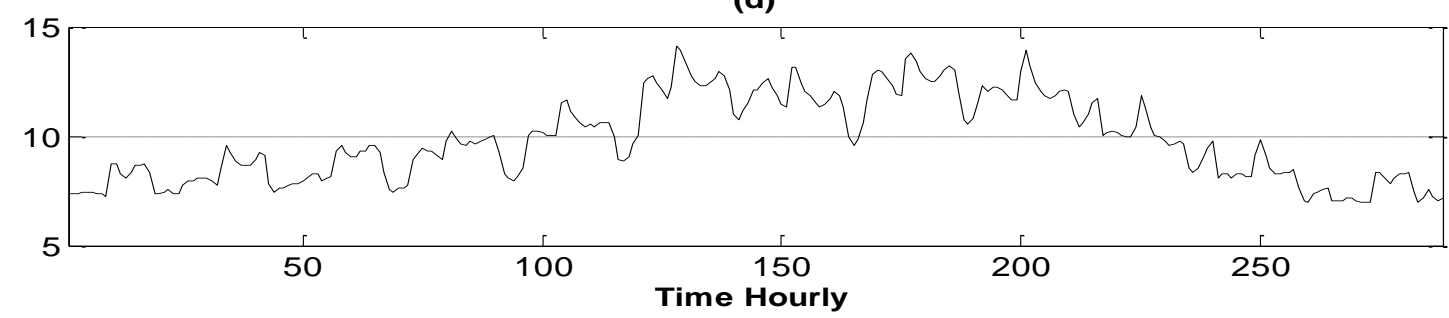

Fig.5: Wind speed with wake effect of wind farm: (a) wind speed at row1 (b) wind speed at row2 (c) wind speed at row3: (d) wind speed at row4

The energy produced by the turbines account with a change in wind speed and that is the most appropriate value for tip speed ratio $\lambda_{\text {opt }}$ as well as the Power coefficient $\mathrm{C}_{\text {pmax. }}$ by the change in the angular velocity of the wind turbine generator with variable pitch angle $\beta$. Maximum power production for turbine with varying wind speed shows in Fig. 6 . Figure 7, shows maximum power coefficient $C_{p m a x}$. The Pitch angle control" will be set the angle of bleed at suitable value for the $\beta$ with varying wind speeds as shown in Fig. 8. The tip speed ratio, TSR control" has been set to the most suitable value for the TSR $\lambda_{\text {opt, }}$, as shown in Fig. 9.

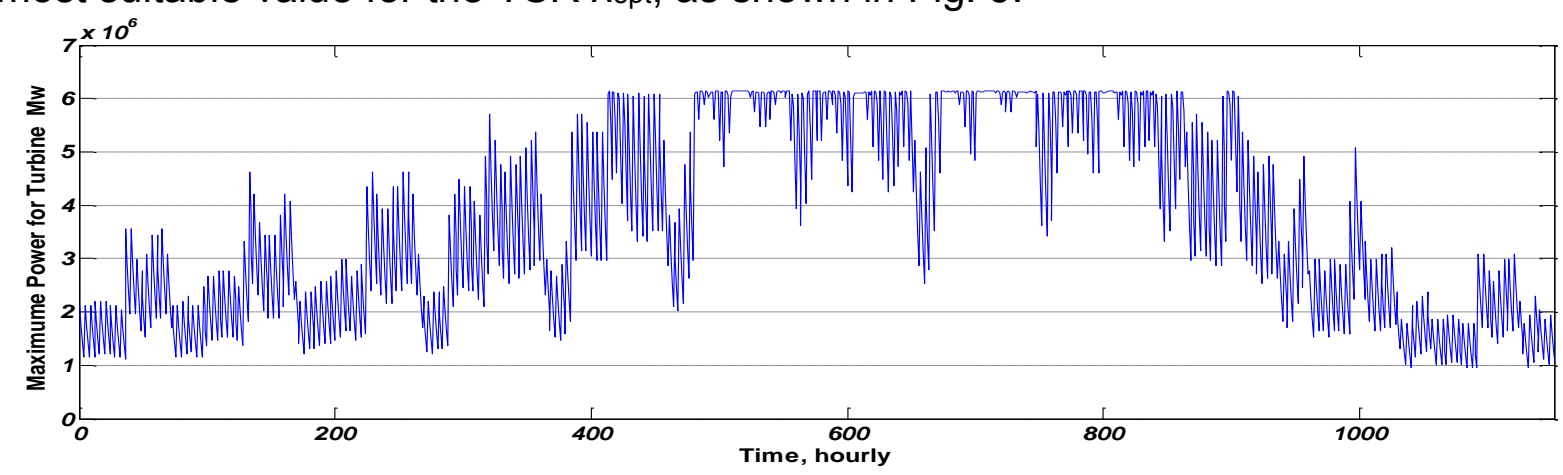

Fig. 6 Maximum power production for turbine with varying wind speed 


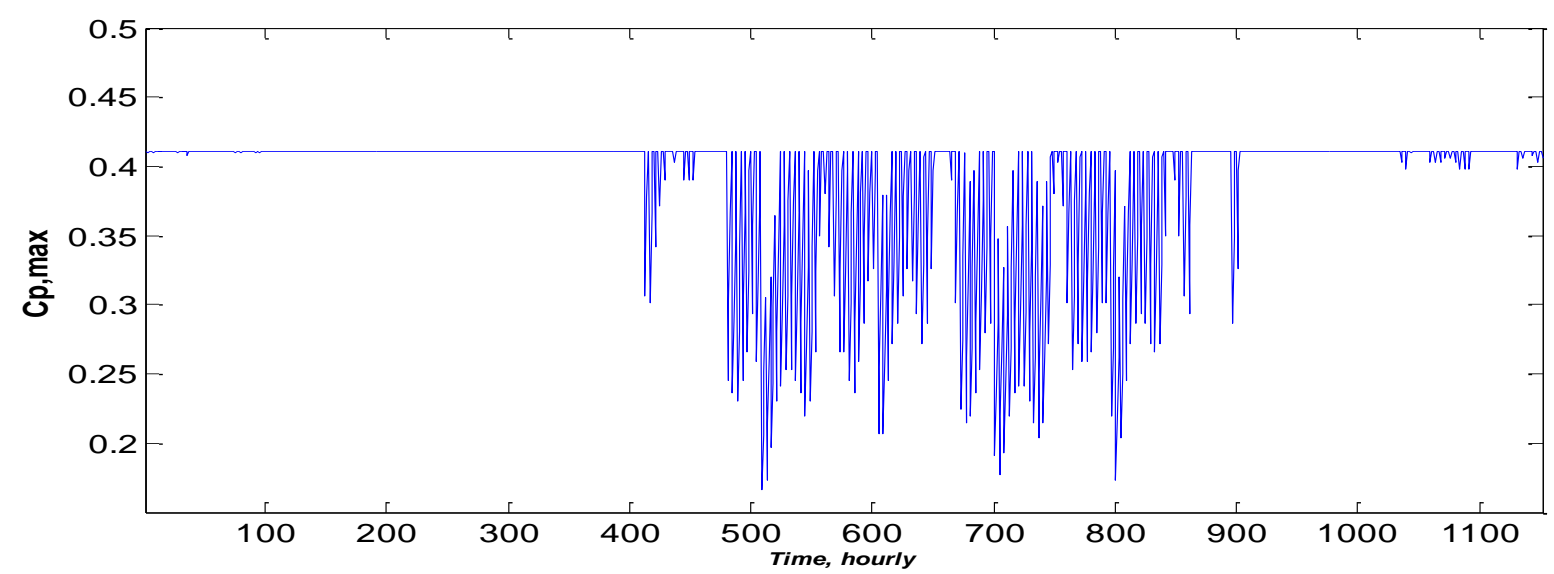

Fig. 7 maximum power coefficient $\mathrm{C}_{\mathrm{pmax}}$

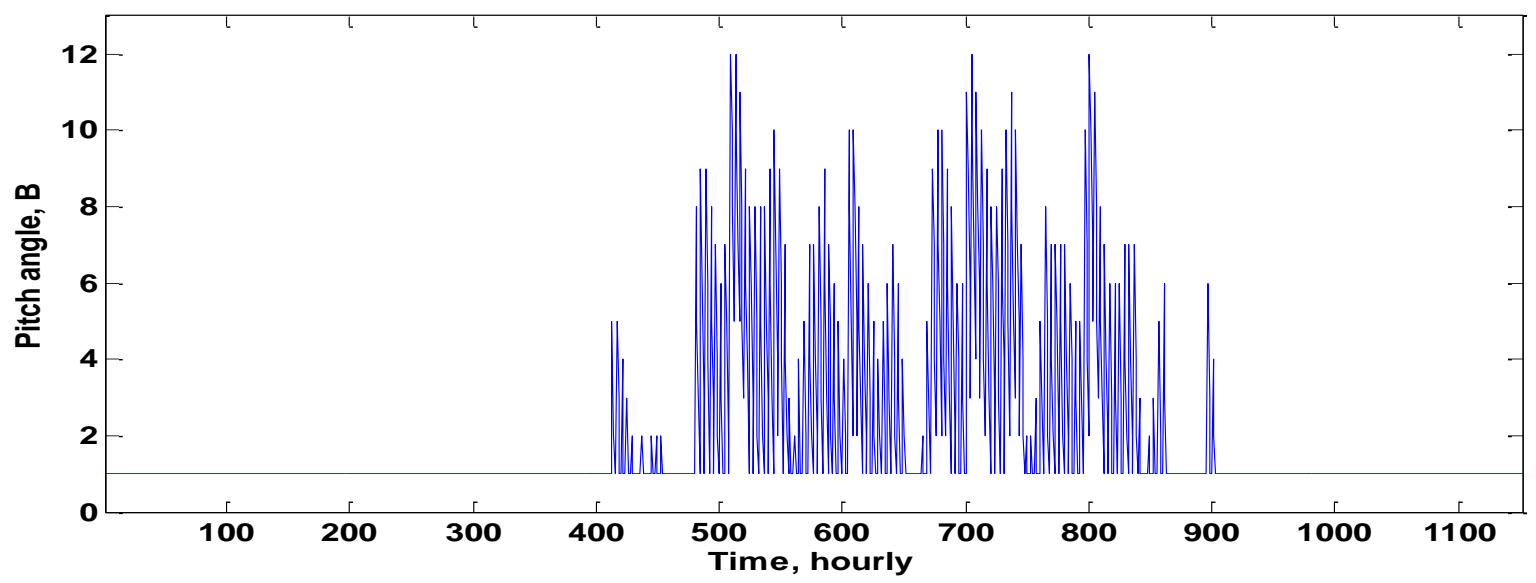

Fig. 8 pitch angle $\beta$ with varying wind speed

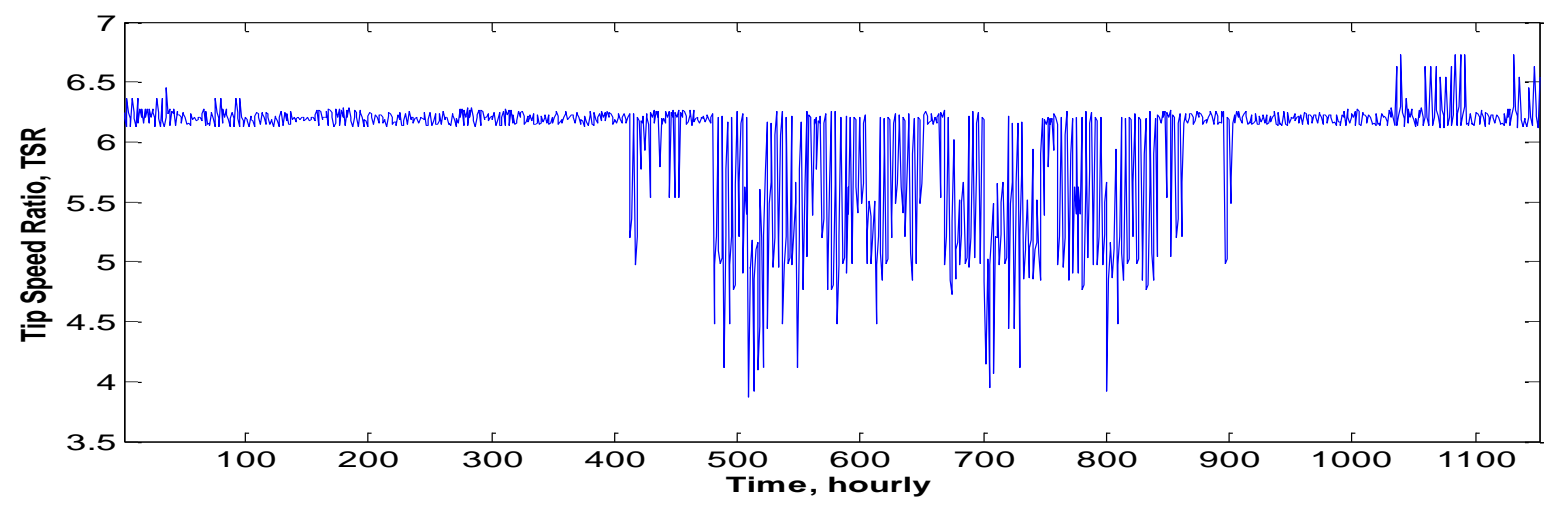

Fig. 9 Tip speed ratio, $\lambda_{\text {opt }}$ with varying wind speed

In the case of the thumb wind farm module the Repower wind turbine produces yearly energy more than other turbines. This can be shown as in Table (2). From this table it can be seen that:-

1. The Repower wind turbine produces yearly energy more than the GE wind turbine with $46.71 \%$ w. r. to the output of Repower wind turbine and less cost objective function.

2. The Repower wind turbine produces yearly energy more than the SWT wind turbine with $28.58 \%$ w. r. to the output of Repower wind turbine and less cost objective function. But the cost for SWT is less than the cost of Repower wind turbine with $5 \%$. 
3. The Repower wind turbine produces yearly energy more than the FD wind turbine with $\quad 43.5 \%$ w. r. to the output of Repower wind turbine and less cost objective function.

4. The Repower wind turbine produces yearly energy more than the CT wind turbine with $27.16 \%$ w. r. to the output of Repower wind turbine and less cost objective function.

TABLE-2: Design parameters of the thumb wind farm using different selected wind turbines.

\begin{tabular}{|c|c|c|c|c|c|c|c|}
\hline $\begin{array}{c}\text { Type of } \\
\text { Turbine }\end{array}$ & $\begin{array}{c}\text { Distance } \\
\text { between } \\
\text { turbine } \\
\mathrm{m}\end{array}$ & $\mathrm{N}_{\text {row }}$ & $\mathrm{N}_{\mathrm{col}}$ & $\mathrm{N}$ & $\begin{array}{c}\text { Yearly } \\
\text { Energy } \\
\text { Production } \\
\text { MWh }\end{array}$ & $\begin{array}{c}\text { cost } \\
\text { per } \\
\text { unit of } \\
\text { energy }\end{array}$ & $\begin{array}{c}\text { Objective } \\
\text { Function }\end{array}$ \\
\hline $\begin{array}{c}\text { GE 1.6- } \\
100\end{array}$ & $8.5 \mathrm{D}$ & 5 & 21 & 105 & $1.1951^{*} 10^{6}$ & 70 & $5.86^{*} 10^{-5}$ \\
\hline $\begin{array}{c}\text { SWT 4- } \\
130\end{array}$ & $9 \mathrm{D}$ & 4 & 16 & 64 & $1.6015^{*} 10^{6}$ & 42.6 & $2.67^{\star} 10^{-5}$ \\
\hline $\begin{array}{c}\text { FD77- } \\
1500\end{array}$ & $8.5 \mathrm{D}$ & 6 & 27 & 162 & $1.2670^{*} 10^{6}$ & 108 & $8.52^{*} 10^{-5}$ \\
\hline $\begin{array}{c}6 \mathrm{M}- \\
\text { repower }\end{array}$ & $9.5 \mathrm{D}$ & 4 & 17 & 68 & $2.2425^{*} 10^{6}$ & 45.3 & $2.02^{*} 10^{-5}$ \\
\hline $\begin{array}{c}\mathrm{C} \mathrm{T} \\
3000\end{array}$ & $8 \mathrm{D}$ & 5 & 20 & 100 & $1.6335^{*} 10^{6}$ & 66.6 & $4.08^{*} 10^{-5}$ \\
\hline
\end{tabular}

In the case of the predominated wind farm module the Repower wind turbine produces yearly energy more than other turbines. This can be shown as in Table (3).

TABLE-3: Design parameters of the predominant wind farm using different selected wind turbines.

\begin{tabular}{|c|c|c|c|c|c|c|c|}
\hline $\begin{array}{c}\text { Type of } \\
\text { Turbine }\end{array}$ & $\begin{array}{c}\text { Distance } \\
\text { between } \\
\text { turbine m }\end{array}$ & $\mathrm{N}_{\text {row }}$ & $\mathrm{N}_{\text {col }}$ & $\mathrm{N}$ & $\begin{array}{c}\text { Yearly } \\
\text { Energy } \\
\text { Production } \\
\text { MWh }\end{array}$ & $\begin{array}{c}\text { cost per } \\
\text { unit of } \\
\text { energy }\end{array}$ & $\begin{array}{c}\text { Objective } \\
\text { Function }\end{array}$ \\
\hline $\begin{array}{c}\text { GE 1.6- } \\
100\end{array}$ & $8.5 \mathrm{D}$ & 5 & 21 & 105 & $1.0504^{*} 10^{6}$ & 70 & $6.66^{*} 10^{-5}$ \\
\hline $\begin{array}{c}\text { SWT 4- } \\
130\end{array}$ & $9 \mathrm{D}$ & 4 & 16 & 64 & $1.5058^{*} 10^{6}$ & 42.6 & $2.85^{*} 10^{-5}$ \\
\hline $\begin{array}{c}\text { FD77- } \\
1500\end{array}$ & $8.5 \mathrm{D}$ & 6 & 27 & 162 & $1.0545^{*} 10^{6}$ & 108 & $10.21^{*} 10^{-5}$ \\
\hline $\begin{array}{c}6 \mathrm{6M}- \\
\text { repower }\end{array}$ & $9.5 \mathrm{D}$ & 4 & 17 & 68 & $1.9367^{*} 10^{6}$ & 45.3 & $2.34^{*} 10^{-5}$ \\
\hline C T 3000 & $8 \mathrm{D}$ & 5 & 20 & 100 & $1.3932^{*} 10^{6}$ & 66.6 & $4.79^{*} 10^{-5}$ \\
\hline
\end{tabular}

From this table it can be seen that:-

The Repower wind turbine produces yearly energy more than the GE wind turbine with $45.76 \%$ w. r. to the output of Repower wind turbine and less cost objective function.

1. The Repower wind turbine produces yearly energy more than the SWT wind turbine with $22.25 \%$ w. r. to the output of Repower wind turbine and less cost 
objective function. But the cost for SWT is less than the cost of Repower wind turbine with $5 \%$.

2. The Repower wind turbine produces yearly energy more than the FD wind turbine with $\quad 45.55 \%$ w. r. to the output of Repower wind turbine and less cost objective function.

3. The Repower wind turbine produces yearly energy more than the CT wind turbine with $28.06 \%$ w. r. to the output of Repower wind turbine and less cost objective function.

\section{CONCLUSION}

From the study results described above it can be concluded that the power output in the case of the thumb is greater than that the power output in the case of predominant for each turbine under study as follows:

Use GE wind turbine increases energy production with the rate of $12.11 \%$. Use SWT wind turbine increases energy, production with the rate of $5.98 \%$. Use FD wind turbine increases energy production with the rate of $16.77 \%$. Use Repower wind turbine increases energy production with the rate of $13.64 \%$. Use CT wind turbine increases energy production with the rate of $14.71 \%$. So, the thumbs wind farm module is appropriate in the design of the high productive capacity and low cost for the rest of the roads.

\section{References}

[1] Handbook Dr. Gary L. Johnson "Wind Energy Systems", electronic edition October 10, 2006

[2] S. Heier, Grid integration of wind energy conversion systems, JohnWiley \& Sons Ltd, Chichester, 1998

[3] Brendan Fox, Leslie Bryans, Damian Flynn, Nick Jenkins, David Milborrow, Mark O'Malley, Richard Watson and Olimpo Anaya- Lara "Wind Power Integration Connection and System Operational Aspects"@ The Institution of Engineering and Technology Book Second Edition 2014

[4] Michele Samorani, P. M. Pardalos et al. (eds.), Handbook of Wind Power Systems, Energy Systems, DOI: 10.1007/978-3-642-41080-2_2, _ SpringerVerlag Berlin Heidelberg 2013.

[5] Jensen NO, 1983. A note on Wind Generator Interaction. Riso National aboratory, Roskilde, mark

[6] Marmidis G, Lazarou S, Pyrgioti E. Optimal placement of wind turbines in a wind park using Monte Carlo simulation. Renewable Energy 2008;33: 1455-60

[7] Sisbot S, Turgut Ö, Tunç M et al (2010). Optimal positioning of wind turbines on Gökçeada using multi-objective genetic algorithm. Wind Energy 13:297306

[8] Hassan H. El-Tamaly, Ayman Yousef Nassef. "Tip speed ratio and Pitch angle control based on ANN for putting variable speed WTG on MPP", 2016 Eighteenth International Middle East Power Systems Conference (MEPCON), 2016

[9] "College of Engineering: Wind Turbines", 21 June 2010 [Online]. Available: http://people.bu.edu/dew11/windturbin e.html. [Accessed 10 March 2014] 